\title{
SONS OF CONSOLATION.
}

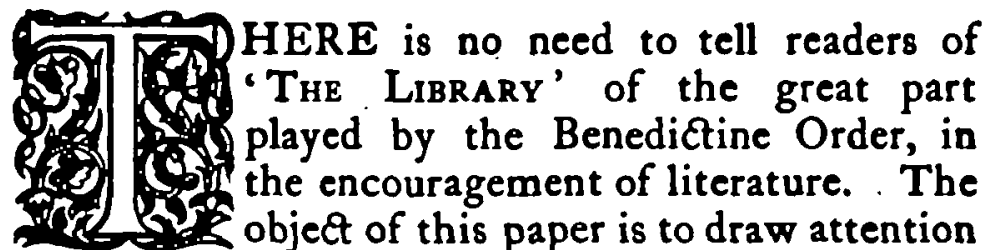

to an interesting little book entitled 'Torquato Tasso e i Benedittini Cassinesi,' published in Rome in 1886 , in which the author, Dom Luigi Tosti, himself a monk of Monte Cassino, tells how the poet Tasso, in all the sorrows of his life, received comfort and help from Benedictines. These cultured men understood that the troubled soul of a great poet needed their ministrations as much as the bodies of the poor and sick. If the world dealt hardly with Tasso, and if princes persecuted him without a cause, yet from one class of men he met with unfailing kindness and sympathy. From his cradle to his grave he found consolation in the charity of monks, especially from the Brethren of the Order of St. Benediet.

In 1 545, a year after the birth of Torquato, his father left Sorrento and went to settle in Salerno, in the service of Ferrante Sanseverino, its Prince. The birthplace of the poet was at Sorrento; beautiful even now, in spite of the hideous hotels and advertisements and funicular railways, which cannot altogether spoil the blue 
sea, and the orange groves, and the view of Naples and Vesuvius, But if his birthplace was beautiful, still more lovely is the Gulf of Salerno, where his childhood's days were spent. Those who have once dwelt on its shores long to revisit them; to walk once more in the lemon groves above beautiful Amalfi, stretching out white and glittering into the opal-tinted sea; to climb the green hills of La Cava; and to marvel at the strange, half-Moorish architecture of the once powerful fortress-town of Ravello.

To all these scenes attaches the patbetic interest of fallen greatness. It is difficult to believe that thore were once Princes of Salerno and Doges of Amalfi, and that through the gates of ruined Ravello splendid cavaliers in armour used to ride forth with their trains of followers.

All these scenes were well known to the child Torquato, but we learn from his own words that the spot in that favoured region that most deeply impressed his childish imagination was the Benedietine Monastery of SS. Trinità at Corpo di Cava. This celebrated Abbey, high up among the mountain-tops above the village of Corpo di Cava, was founded in Ior I by Alferio Pappacorbone, cousin of Guaimario III, Prince of Salerno, Every turn of the winding mountain road from Salerno to the Monastery displays fresh beauty, At Vietri you regretfully leave behind you the blue waters of the gulf and its distant coast lines to turn inland; but new beauties await you as, after passing the little arcaded town of La Cava, you climb ever higher and higher among the mountains; getting glimpses 
of the sea and of the distant peaks of Monte Vergine, always covered with snow.

One of the finest points of view is in front of the Chapel of the Pietra Santa, built to commemorate the visit of Pope Urban II, the preacher of the first Crusade, in I092, to consecrate the Church of the SS. Trinita. Inside the chapel a bare mass of rugged rock rises up before the altar. This plain specimen of unadorned nature has a strange effect among the artificial flowers and images of the chapel. It is like the threshing-floor of Araunah the Jebusite among the splendours of the gorgeous temple of Solomon.

On this rock Pope Urban dismounted and told the bishops and cardinals who followed him that they were on holy ground, and that only on foot must they approach the Grotto where had dwelt the saintly Alferio and his holy followers.

The Church of the Monastery is built above the Grotto, which is still to be seen in the crypt where Alferio is buried, and where rest the remains of many princes and great men, for it was esteemed a privilege to be buried there in holy earth brought from Jerusalem. The Monastery, like that of Monte Cassino, is now a place of education, and boasts of a splendid library, with a beautiful collection of old missals, and a Bible of the seventh century presented by Sant Alferio in 1035. In that library the antiquary can gloat over old parchments and examine at his leisure Papal Bulls, deeds conveying 'Morning Gifts' from princes to their brides, and charters going back to the eighth century.

To this spot, so rich in historical interest and so 
full of beauty, the child Tasso was often brought by his father. He tells us of the kindness he received there; how the abbots used to caress him and the monks to tell him the stories of the house, which could boast of several saints and two popes. Following some monk as a guide with a torch into the crypt, the child would see figures of saints with golden halos looming strangely out of the semidarkness from the frescoed walls, and great piles of bones and skulls said to be remains of Norman and Lombard princes.

He used to wander among the beautiful regions around the Abbey, among the high hills, and by the cascade made by the little river Selano casting itself eagerly over the rocks to rush on its course to the Gulf of Salerno. Here, in spring, the maidenhair fern grows thickly and the green slopes are starred with pale primroses, violets of every shade, and lovely, fragile, pale blue anemones.

Such were the scenes in which the child poet listened to kind monks telling him the stories of the past. He tells us that what he loved best to hear was about the Crusades and of the part played in them by that great Pope, Urban II, who had himself been a monk of La Cava.

Undoubtedly, we find the origin of Tasso's great poem of the 'Gerusalemme Liberata' in the impression made on his youthful mind by the pieturesque stories of the Crusades told to him by the monks of La Cava.

It is very touching to find him, long afterwards in the sad time of his imprisonment, writing to his friend, Angelo Grillo, of the happy days 
of his childhood in the beautiful monastery of La Cava. He tells the same Angelo Grillo that in his poem of the 'Gerusalemme Conquestata' he has made special mention of. Pope Urban and of $\mathbf{L a}$ Cava, and in that poem (canto III, stanza iv) we find lines describing the tapestries with which the tent of Godfrey was decorated, and among the scenes, wrought in them in gold and colours, was the valley of $\mathrm{La}_{2}$ Cava and its holy recesses, and walking among them, Urban in his monk's dress.

This is not a biography of Tasso, but an attempt to trace out the part played in his life by his monastic friends; still, before speaking of his imprisonment it is necessary to allude briefly to the causes which led to it.

Whether the poet was mad, why he was imprisoned, and if he really loved Eleonora d'Este are questions which seem destined never to be satiofaftorily answered. It is certain that, when still very young, Tasso entered into the service of Alfonso II, Duke of Ferrara, at whose court dwelt the duke's two sisters, Lucrezia and Eleonora. We hear often in the present day the complaints of authors as to what they have to endure from public and publishers; but the men of letters of the past must have suffered much worse things at the hands of their noble and princely patrons. We know Dante's opinion of the bitterness of the bread of others; Tasso, no doubt, fully shared it.

The poet who lived at a great man's. court had to sell his talents to his master, and to amuse the leisure of great ladies when time hung heavily on their hands. 
Tasso enjoyed familiar intercourse with Lucrezia and Eleonora. He read his poems to them when they were alone, and was much in their society. What wonder if he fell in love with the beautiful Eleonora, who was delicate in health, of a reserved disposition, and somewhat of a recluse, with a certain mystery about her, likely to attract the imagination of a poet? We all know the story of a princess of France seeing a poet asleep in the sunshine, and stooping to kiss him, to the amazement of her ladios. She explained to them that the kiss was not for him, but for the sweet words his lips had spoken. How is the poet to know if great ladies caress him with flattering words, that their praises are not for him as a man, but for the power of his genius which can spread the fame of their beauty? If holy hermits found temptation in the wilderness, what must not poets, with hearts aflame with the love of the beautiful, and exalted imaginations, have found in intercourse with lovely and gifted princesses? Chastelard, dying on the scaffold for daring to love a beautiful queen, may be regarded as the chief martyr of court poets. It certainly seems probable that it was for raising his eyes to a royal lady that Tasso suffered his terrible imprisonment among the crazy inmates of the hospital of Sant' Anna, in Ferrarax

In March, 1 579, Tasso was confined there, under strict guardianship, as a madman. He complains, in a letter, that he is deprived of all solace alike of mind and body; that the chaplain never visits him, and that he cannot confess or communicate.

Whether Tasso was a victim to the caprice of 


\section{$33^{6}$ SONS OF CONSOLATION.}

the Duke of Ferrara, or to the rigours of the Inquisition, it is equally to the credit of the brothers of Saint Benedict that they continually visited him when he was sick and in prison. No sooner did the lamentations of the unhappy prisoner reach the ears of the Brethren than from La Cava, San Severino, Monte Cassino, and Ferrara itself hands of compassion were stretched out to him, and pitiful hearts were touched by his tale of woe. The most faithful of his monastic friends was Dom Angelo Grillo, a man of noble birth and considerable intellectual attainments. He turned his back on wordly honours and became a monk, and afterwards refused promotion in the Church, thinking even clerical honours inconsistent with his monastic vows. He was a student of philosophy, a friend of poets, and a poet himself. His compassionate heart could even feel for a dead poet, for he tells us that being once near Arqua he was led to think of Petrarch, and that, after visiting his house, he and all his monks prayed for him, and he says: 'I have ordained a solemn anniversary for that great, and as I consider him, blessed and holy soul, that God may have him in a place of light and glory.'

In what appears to be his first letter to the poet, as printed by Dom Luigi Tosti, Grillo offers himself to his notice with the utmost modesty, and invites him to rely upon him for help.

Being unable himself at that time to go to Sant' Anna, he arranges for a certain Dom Basilio Zaniboni, of the Monastery of Ferrara, to visit the prisoner.

In the letters of Grillo, Basilio is called the 
'Cellerario.' The officer, so called in the rules of Saint Benedict, has to minister to all the temporal wants of the Brethren. He is exhorted to fear God and to be as a father to all the Community. 'Do not sadden the brothers,' says Saint Benedict. 'Let him'-i.e., the Cellerario-' care, with all tenderness, for the sick, for children, for guests, and for the poor, holding it for certain that for all these he will have to give account at the Day of Judgement.'

It was no light task that Basilio took upon himself when he became the consoler of the poet. Tasso had lost hope in man; he had become moody and irritable, and his powerful mind, for a time, was reduced to almost childish weakness. Luigi Tosti says: ' Tasso in the cares of D. Basilio took the place of the sick, of the child, of the guest, of the poor; and the cellerario could render at the day of judgment good account of his dealings towards Torquato.'

The letter of Angelo Grillo at once roused Tasso to mental exertion. He told Basilio that he could not at once answer it because be wished to reply to the sonnets in it with other sonnets.

Tasso says: 'I have not, for many years, had a letter that I have read with greater pleasure than the one written to me by Dom Angelo.'

While Grillo sent him sonnets, the kind and simple Basilio sent, with his letters, presents of candies and preserved peaches. Tasso thanks him for these, but gives him to understand that he is eager rather for heavenly than for earthly food. He probably liked the peaches all the same. 


\section{$33^{8}$ SONS OF CONSOLATION.}

Tasso replied tc the two sonnets of Grillo with two others, and alluded, in his letter to Grillo, to the kindness he had received in childhood from the monks of $\mathrm{La}$ Cava, and hoped that the charity of the past would not fail him in his present misfortunes.

Grillo obtained leave from the duke to stay with Tasso in his prison, an act of sublime charity, for those who visited him speak of his wretched condition, of the squalor of his dress, his neglected beard, his gloom and depression caused by solitude, which he calls his cruel and natural enemy.

Tosti says: "If one tear only fell upon the serge of the monk, that tear was the most splendid decoration that could adorn the breast of a Benedictine.' Grillo thought Tasso's continual complaints undignified, and tried to wean him from them. He writes: 'You are miserable, Signor Tasso, because you are human, not because you are unworthy! If a manifest unhappiness did not distinguish you from other men, from the works of your divine intellect you might be looked upon as something divine, which God does not will in this world because you can in very deed become divine in the other.'

Grillo induced the Duchess of Mantua to write to the Duke Alfonso and to her daughter, Margherita, his wife, on behalf of Tasso. She obtained for him a great betterment of his condition. He was to be allowed sometimes to go out to visit churches and convents, to enter into the society of noble dames and cavaliers, and to feast his' eyes on the spectacle of jousts and tournments, which were 
splendid at Ferrara during the carnival of the year 1584 .

Short respite! The sight of tournaments and beautiful ladies and the repose of quiet monastic cloisters were soon taken from the unfortunate Tasso. He was lured back to his prison bye the duke on the pretence that a friend was waiting there to see him, and when he turned to leave it again guards with swords opposed his exit. Poor Grillo had once more to listen to his furious complaints. In the meantime several editions came out of the 'Gerusalemme.'

The name of Tasso was held up to honour till a discussion arose as to the, respective merits of Tasso and Ariosto. Party spirit ran high, and the partizans of Ariosto indulged in the cruellest mockery of Tasso and his works. The poor poet, wearied with imprisonment, was conquered body and soul by the insults of his literary enemies. The one thing which had sustained his courage was the hope of living for ever in his works. He owned, in a letter to Grillo, that he had always feared death more than a true philosopher ought to, but that now, when that which had seemed to him to be his immortal part was attacked, he longed for any escape from his misery. Tosti considers that the sympathy of Grillo saved him from suicide, and that Tasso owed it to him that, 'instead of dying at Sant' Anna with a phial of poison in his hand, he fell asleep at Sant' Oriofrio in the arms of $\mathrm{Him}$ who is the Living Bread for the salvation of the world.'

Grillo's efforts in the release of Tasso were ${ }_{24}$ unremitting, in spite of all he had to endure from 
the impatience and importunity of the sufferer he was trying to help.

Tasso sent verses to the duke's sister, the Duchess of Urbino, and he once wrote wishing to kiss the hands of Eleonora when she was weak and near to death; but we do not know if the message ever reached her.

The monk and the Duchess obtained for him the favour of release from prison for one day! He spent it in the house of Donna Marfisa d'Este, a brave and beautiful lady, who appears to have surrounded herself with a bevy of lovely and charming women for the occasion. The faithful Grillo provided a carriage for the prisoner to go out in.

What a ghastly contrast! To go from the glimpse of Paradise with the lovely ladies to whom doubtless could be addressed the words of Dante, 'Donne ch' avete intelletto d' amore,' back to the Inferno of the solitary cell, and the shrieks of the maniacs at gloomy Sant' Anna.

Grillo had now, for a time, to leave Ferarra. He writes to his brother that to imprison himself with Tasso was more sweet to him than any liberty or any recreation. Besides Zaniboni, others of the Brethren watched over the poet. One of themCostanzo Sonzino-endeavoured to moderate his melancholy and fantastic humours. The loving and anxious Grillo seems to have feared lest the precious balms of the well-meaning monk might break the poet's head, for he writes to him that 'delicate things need delicate handling, and these subtle minds are like glasses, that if in washing are much pressed easily come to be broken.' Grillo not only tried to bring about the liberation of 
Tasso; he also laboured to bring out an illustrated edition of the 'Gerusalemme,' and sent an artist named Castelli to see Tasso, and, ever careful for his friend's reputation for sanity, begged him to give a friendly reception to the visitor.

One friend, going to see Tasso, had been unable to draw a syllable from his lips; but to the artist he was agreeable, and Castelli gave him a picture of Christ, on which Tasso wrote a sonnet. Grillo received a most beautiful picture of Erminia. Luigi Tosti says: 'Strange giver, Castelli!-To Tasso, the Christ, and to P. Grillo a most beautiful Erminia. But the monk, who had "la religiosità senza fuoco," was not scandalized; he received the gift, and celebrated it, he also, with a sonnet.'

From Tasso's own words we gather that his mind often hovered in that debatable region between exalted imagination and insanity, where the minds of solitaries seem often to dwell. He heard strange voices; inanimate things seemed to speak to him ; and everything appeared to assume to him a terrible and threatening aspect. It is wonderful that, being alone or with mad men for seven years, he retained any mental health at all. Angelo consoled and helped him in his difficulties with the Inquisition, and listened to his many demands, including a request for a doctor from Monte Cassino, and that a goat might be sent to him that he might have whey. Moreover, the Order of Saint Benedict conferred on him a signal mark of favour.

It was a very ancient custom for the Benedictines to receive into their spiritual confraternity eminent laymen and ecclesiastics who had merited 


\section{SONS OF CONSOLATION.}

such a favour by special services and devotion to the Order. The recipient of such an honour was informed of it by a letter termed 'Lettera Graziosa.' Saint Benedict himself is supposed to have been the first to write such letters, and Boniface, the apostle of Germany, and Alexis, Emperor of Constantinople, were among the illustrious recipients of them.

It was resolved to bestow this great mark of distinction upon Tasso, and Angelo Grillo sent Dom Basilio to tell him that his name was to be inscribed in the lists of the confraternity of Saint Benedict. Kind Basilio, ever mindful of the wants of the body, took with him some sweets for the prisoner to eat. Tasso wrote a touching letter to Grillo thanking him for the promised honour, and saying, "I hope to be a son, not of anger and malediction, but of light and resurrection, for certainly I am already dead in sin, dead in the opinion of men, dead in the favour of many princes and lords who were and are loved and remembered by me.'

Tosti calls the 'Lettera Graziosa' the plank to which Tasso clings in his shipwreck.

The longed-for letter came at last, carried to Tasso by a servant, a circumstance which excited the wrath of the irritable poet, who wrote an indignant letter to Grillo, saying that he took it as a sign that the Brothers had abandoned his soul. He could not see that the Benedictines feared to draw down the wrath of Alfonso on their brethren of Ferrara, if they too openly honoured a man declared by the powerful noble to be mad.

There were great festivities at the Courts of Ferrara and Mantua over the marriage of Cesare 
d'Este and Virginia de' Medici. Grillo felt the gathering of princes to be an opportunity of helping the cause of Tasso. He did not hesitate to dwell amongst them, saying that he had learnt to be a monk in the midst of a court. Principally through the good offices of Vincenzo Gonzogo, son of William, Prince of Mantua, he first obtained leave for the prisoner sometimes to go out of his prison, and finally consent to his complete liberation was wrung from the unwilling Alfonso.

In July, 1586 , the singer of the 'Gerusalemme Liberata' came out, a free man after seven years of captivity. He was taken to the Court of Mantua, where he was honoured and caressed; but he did not forget his Benedictine friends, and his first thought was to go to a monastery for confession and to return thanks to the Madonna, who had appeared to him in a vision with Saint Benedict and Saint Scholastica.

Angelo Grillo still worked on his friend's behalf, trying to make him take a post to teach Aristotle at the Academy of Genoa, when Tasso fancied that the Princes of Mantua were tired of him. Grillo even laboured to get from Naples money that ought to come to Tasso from his mother's dowry. Well might Tasso say, 'Dom Angelo loses no occasion of showing to me the esteem in which he holds an unfortunate gentleman.'

In the nine years between the time of his release and the hour of his death Tasso often found rest and refreshment in some Benedictine cloister, and it is interesting to know that his last Christmas 20. was spent in the very home of the Order, in the 


\section{SONS OF CONSOLATION.}

celebrated monastery of Monte Cassino itself, where Saint Benedict dwelt and displaced the worship of Apollo. Apollo and the muses seem to have lingered in their ancient haunt, and to have infused something of their spirit into the intellectual and liberal-minded monks who were such faithful friends to the inspired poet. Surely Grass of Parnassus flourished on the slopes of Monte Cassino!

At the Holy Mount Tasso found a varied collection of Brothers, some already known to him. Amongst the company were two Englishmen, called by Tosti 'dottissimi,' and a Knight of Malta who had fought at the battle of Lepanto. Tasso and the monks spent the eve of Christmas high up on the mountain, watching the joy-fires being kindled in the valleys below.

The end of Tasso's story is too familiar to need telling in detail. We all know how he was summoned to Rome to walk in a triumphal procession to be crowned with laurels at the Capitol; and how death found him at the beautiful peaceful monastery of Sant' Onofrio, before the day dawned which was to mark his country's recognition of his genius.

At the time of the Tasso Tercentenary in 1895 , the writer of this paper was in Italy with a party of friends, and spent a delightful Sunday visiting the monastery of La Cava, where a very intelligent young monk showed us all the most precious treasures of the library, and b*gged us to read the book about Tasso by Dom Luigi Tosti. We tried in vain to get it in Rome; but all things are 


\section{SONS OF CONSOLATION.}

possible to a London bookseller, and so we obtained it on our return to England.

On another Sunday we visited Sant' Onofrio, where, three hundred years before (on 25 th April, I 595), the weary soul of the poet had found rest. We walked in the frescoed cloister, once paced by the feeble steps of the dying man, and entered the little cell-like, white-washed rooms, where his last hours had been spent. Interesting relics of the poet had been gathered there; portraits of him, with the over-hanging brow and the great sad eyes that haunt us after we have gazed on them; always with the laurel leaves that he never wore in life, leaves which Dante says in his invocation to Apollo are so seldom gathered for triumph of Cæsar or of Poet.

The peaceful, white room, with the floor strewn with evergreens, the numerous wreaths, the chair, the pen, the crucifix that the dying man had used, all as he had left them, made it seem as if Death had been there quite recently, and not as if three hundred years had passed away since the poet had been laid in his grave.

In the dark church, rich in the glowing colours of the decorations of Pinturicchio, fresh laurel wreaths were piled on the stone that bears the name of Torquato Tasso.

After all, the enemies the poet feared had not triumphed. He had won his place, not indeed on the summit with Dante, but still high on the fair hill of Italian poetry, full in the sunshine of remembrance.

Claudia E. Gale. 